\title{
The Problem of Women's Agency in Late Medieval and Early Modern Europe
}

\author{
Martha Howell
}

In the last few decades, historians have regularly used the term "agency" to frame their studies of historical actors, probably none more so than historians of late medieval and early modern women. Witness, to cite just a few recent examples, all treating European women from roughly 1300 to 1800: Gender and Change; Agency, Chronology and Periodisation (2009); Women, Agency, and the Law, 1300-1700 (2013); Female Agency in the Urban Economy: Gender in European Towns, 1640-1830 (2013); Women and Portraits in Early Modern Europe: Gender Agency, and Identity (2008); Women's Agency in Early Modern Britain and the American Colonies, (2007). Even when not specifically included in the titles of books or articles, the word "agency" is laced throughout innumerable scholarly investigations published in the last several years. ${ }^{1}$ Although such studies describe women in different settings and with dissimilar capacities, the women in such studies are credited with agency because in some way they seem to have skirted or even reshaped the patriarchal structure of their day. In that respect, these studies imply, they are to be distinguished from the women who acted in full accord with patriarchal norms, even if they may have done so reluctantly.

This research has measurably enriched and complicated the historical record. Most of the women's historians publishing during the last half century or so necessarily concentrated on correcting an historical record that had all but ignored women, thus seeking to expose what were usually described as "women's roles" in society. ${ }^{2}$ Although some of the studies inevitably featured

1 For one of many examples, see Patricia Crawford, "Women's Dreams in early modern England," History Workshop Journal 49 (Spring, 2000): 129-41, where she remarks that "The dreams I have selected for discussion reveal women as historical agents, actively shaping the meanings in their lives, and offering these interpretations to others.": 130.

2 For representative examples see articles such as James B. Collins, "The Economic Role of Women in Seventeenth-Century France," French Historical Studies, Vol. 16, No. 2 (Autumn, 1989): 436-470; Suzanne Desan, "The Role of Women in Religious Riots During the French Revolution," Eighteenth-Century Studies, Vol. 22, No. 3, Special Issue: The French Revolution in Culture (Spring, 1989): 451-468; or Wes Harrison, "The Role of Women in Anabaptist Thought 
women who challenged male authority in some way, these scholars were principally concerned to demonstrate women's importance to the societies in which they lived, not to unearth evidence of challenges to male dominance. This did not mean, however, that the women were powerless. We might even argue that they too had agency, if we take the oED's definition of agency as the "ability or capacity to act or exert power," for these women certainly found ways to protect and advance their own interests.

However, scholars explicitly examining women's agency intend to do more than document women's "roles" in society. And, as they urge, we do need to identify those moments when the expectations surrounding gender roles and gender identities were challenged or changed, and we need to clarify the part women themselves played in producing these disruptions. We also need to be attentive, as the recent work on women's agency tends to be, to the way that social rank, marital status, chronological and geographical location affected women's agency. I want, however, to plead for more rigorous attention to just what powers we are claiming for women when we assign them "agency." I also want to consider how any woman acquired what we are calling agency if we take seriously Marx's point that all historical actors, female or male, may "make their own history, but they do not make it as they please; they do not make it under self-selected circumstances, but under circumstances existing already, given and transmitted from the past." ${ }^{3}$ In what sense then can a woman sufficiently free herself of the patriarchal regime that is "given and transmitted from the past" in order to claim agency?

Scholars describing women's agency in early modern Europe have, in fact, often conceded, as the editors of Women, Agency, and the Law put it, that women agents typically acted "within the hegemonic paradigm of patriarchal authority." In some studies, women's capacity for agency is in fact produced by a feature of the patriarchal structure itself. The volume Married Women and the Law in premodern northwest Europe, for example, explores the way some marital property regimes in northwest Europe could allow married women property and legal rights not anticipated by the principle of coverture fundamental to both English Common Law and continental customary law. Customary laws, for example, often allowed women full ownership of personal goods, what many customs referred to as "goods of her body," thus making valuable assets such as

and Practice: The Hutterite Experience of the Sixteenth and Seventeenth Centuries," The Sixteenth Century Journal, Vol. 23, No. 1 (Spring, 1992): 49-69.

3 Karl Marx, The Eighteenth Brumaire of Louis Bonaparte (1852).

4 Bronach Kane and Fiona Williamson, eds., Women, Agency and the Law (London: Pickering \& Chatto, 2013): 1 . 
clothing and jewels their private property; others did not allow a husband full control over the property his wife brought to the marriage but only guardianship of it; in England women were not uniformly subject to the marital property regime of Common Law but often, alternatively, to the custom of cities or of the manor. ${ }^{5}$ In other studies women's agency arises as they exercise expected roles. Take, for example, the interesting article, "With a Sword drawne in her Hande," in another collection. Framed by a discussion of how the boundaries of the household were understood, negotiated, and contested in seventeenthcentury rural Wales, the article reveals that women aggressively, sometimes using violence, ranged far beyond the domestic space in order to protect their claims to the household and the social rights that accompanied possession of that space. They did so, however, not as transgressors of the reigning gender order, but as legitimate protectors of theirs and their families' status. ${ }^{6}$

In other studies, women agents were expanding traditional roles. For example, we learn that women in early modern Lyon were ubiquitous in the food trades despite guild restrictions that imposed formal restrictions on their participation. The evidence presented suggests that these women entered the market (illegally for the most part) not in search of the power and autonomy that we associate with entrepreneurial status in market economies, but simply as a result of their need for income or their obligation to help out in a family shop. ${ }^{7}$ A study on Copenhagen's licensed working women in the same volume suggests a similar causality: women often acquired legitimate positions in the market as representatives of a husband who was incapacitated or as widowed heads of household. ${ }^{8}$ Looked at in this way, these women were rendered "agents" (i.e., violators of patriarchal norms that would exclude them from certain market sectors) by way of their position in families, by raw economic needs, or by a combination of both. This of course does not diminish the fact that they were "out of place" in a sense - in places women were not supposed to be - and that they were there because they had found ways into markets

5 Cordelia Beattie and Matthew Frank Stevens, eds., Married Women and the Law in premodern northwest Europe (Woodbridge, Suffolk: The Boydell Press, 2013).

6 Niola Whyte, "'With a Sword Drawne in her Hande': Defending the Boundaries of Household Space in Seventeenth-Century Wales," in Kane and Williamson, eds., Women, Agency and the Law: 141-57.

7 Anne Montenach, "Legal Trade and Black Markets: Food Trades in Lyon in the late seventeenth and early eighteenth century," in Deborah Simonton and Anne Montenach, eds., Female Agency in the Urban Economy: Gender in European Towns, 1640-1830 (New York: Routledge, 2013): 17-35.

8 Carol Gold, "On the Streets and in the Markets: Independent Copenhagen Saleswomen," in Simonton and Montenach, eds., Female Agency in the Urban Economy: $35^{-5} 6$. 
supposedly closed to them. In that sense they were indeed agents, but that did not imply an escape from the hierarchal gender system of the day.

Thus, for the most part we read not of women who overturned the patriarchal regime but of those who "negotiated the system" to protect their interests, who "worked around" the constraints of law to achieve a goal not intended by the law, or who "strategically positioned themselves" in ways that benefitted them, all suggesting that agency was achieved by circumventing rather than confronting or altering conventional norms. ${ }^{9}$ Similarly, we have studies that identify the "avenues of female influence in legal cultures," once again implying that agency meant finding routes around patriarchal restrictions. ${ }^{10}$ Although such phrasing does suggest that agency somehow involves weakening or undermining male control, scholars have rarely made overt challenge to masculine authority a measure of agency; in short, the women described in most studies were not "resistant" in that they did not self-consciously or intentionally seek to disrupt the system of male dominance. Some scholars have made that point explicitly. In their Introduction to Female Agency in the Urban Economy: Gender in European Towns, 1640-1830, for example, Deborah Simonton and Anne Montenach explain that:

... agency here is not conceptualized strictly in terms of resistance to male authority or patriarchal patterns, but arose from the variety of everyday interactions in which women accommodated, negotiated or manipulated social rules and gender roles. ${ }^{11}$

Here a woman's experiences qua woman (as defined by the prevailing sociocultural system) gives her the means to acquire "authority and liberty"; although "agency" sometimes even produces "changes within gender relations," such change is not its measure. The "Introduction" to Bronach Kane and Fiona Williamson's Women, Agency and the Law, gives the same credit to "experience" as the source of agency, again however with no insistence that agency

9 One of three sections in a recent volume of essays [Karen Nelson, ed., Attending to Early Modern Women: Conflict and Concord (Newark, Del: University of Delaware Press, 2013)], is, for example, labeled "Negotiations."

$10 \quad$ Kane and Williamson, eds., Women, Agency and the Law: 1. We are sometimes told, in another formulation, about women who "chose" a certain action, thus implying that conscious "choice" is a sign of "agency." Further, Simonton and Montenach, eds., Female Agency in the Urban Economy describe many of the contributions to their volume as studies of "situations in which women could rise above their restrictive situations" and .... could "access authority and liberty.": 4.

11 Simonton and Montenach, eds., "Introduction," Female Agency in the Urban Economy: 5. 
necessarily implies fundamental revision of the gender system or the broader society more generally. ${ }^{12}$ Instead, it arises from women's everyday experiences within the patriarchal regime.

Yet, the terms of gender subordination have changed throughout history and did so as well during the late medieval and early modern period in Europe. Some scholars have explicitly addressed this issue by pointing out that any patriarchal regime is imbedded in - and ineluctably bound to - the larger political, social, economic, or cultural order; it necessarily varies as that order varies. An article in Married Women and the Law, "Peasant Women, Agency, and Status," for example, examined the marked differences in peasant women's property rights and their legal status from region to region in medieval England, showing that some women possessed tenures and had access to courts in their own name, while others had no such status. The author of the study argued that these differences reflected variations in manorial custom, landholding patterns, and economic structure. Thus the question of women's status, she concluded, is not answerable by way of a study of the patriarchal structure alone but:

... needs [in this instance] to be explored within the context of the feudal mode of production .... we need to try to understand gendered relationships within their specific local and manorial contexts ... the structures underpinning oppression and inequalities change, and it is these structures that need to be understood. ${ }^{13}$

Another article implicitly positioned the agency of a young Dutch woman in the religious culture of Dutch Calvinism. By independently seeking to persuade her errant brother to leave the Jesuits and return to the Dutch Reformed Church, she appropriated for herself the paternal role. Her bold actions may well have been owed in part to her personality but arguably she was empowered to take on the usual male role both by the Protestant grant of spiritual authority to the "priesthood of all believers" and the Calvinist insistence that

12 Kane and Williamson, eds., Women, Agency and the Law, 1300-1700 (2013): 2; later in the Introduction, the authors also explain that their study combines investigations of "the intersections of agency, voices, discourse and lived experience," but the emphasis is decidedly on what women did and the situations in which they did it: 5 .

13 Miriam Müller, "Peasant Women, Agency and Status in mid-thirteenth to late fourteenthcentury England: some Reconsiderations," in Beattie and Stevens, eds., Married Women and the Law: 91-113. 
the family was the keeper of the covenant. ${ }^{14}$ In this case, it was the specific culture of her day that allowed female agency. Even such studies, however, do not suggest that women exited or abolished the patriarchal regime - only that it changed, precisely because it was foundational to the entire social order. As one part moved, so did others.

If female agency can be produced by the patriarchal structure itself and by the way that patriarchy is imbedded in the larger complex of social structures, then agency cannot be understood apart from these structures themselves. We are thus returned to an old debate about the relationship between structure and agency, one that has long occupied scholars equipped with powerful social theory drawn, for example, from Marx, Levi-Strauss, or Braudel, In form these models can be perilously determinist, so firm are the structures they posit. Whether rooted in functionalist views of how the economy works, how social order is achieved, or how environment, institutional histories, and mentalité combine, they threaten to so imprison individuals in the logics of the structure that there is nothing to explain except how the structure worked. That problem inevitably made historians cautious about such theorizing. Thus, although many of us have adapted these models in our own studies we have had to work very hard to insert real people's lives into the story as anything more than embodiments of structural imperatives.

The so-called linguistic or cultural turn of the 1970s and 8os, although a response to the limitations of such structuralist theory, and for that reason loosely characterized as post-structuralist, nevertheless seemed to confront historians with a similar problem. In the form provided by certain (limited) readings of Foucault among others, cultural discourse, understood not just as language and ideology but also as institutions of all kinds, including law and informal relations of power more generally, envelops the individual, creating him or her as "agent" only of the discourse itself. There can be, in this understanding, no "agency" in a robust sense of the term. Thus, just as powerfully as the structuralist theories of Marxists or of some sociologists, economists, and anthropologists, discourse in this sense seemed to precede the construction of the subject, making him or her nothing but a "subject position." Understandably, historians rarely took up the full implications of this kind of cultural theory, just as they had mostly avoided the full implications of structuralist social theory. In part, they rejected it because their archives were full of individuals so different from one another that none seemed to perfectly enact the logic of the discourse.

14 Craig Harline, "Big Sister as Intermediary: how Maria Rolandus tried to win back her wayward brother," in Nelson, ed., Attending to Early Modern Women, Conflict and Concord: $3^{-23}$. 
Even more worrying for historians was the difficulty of accounting for change; if the individual - even the self-conscious, intentional individual - was only a product of the discourse, he or she would have no capacity to disrupt the system itself, only to perform a role in it. As a result of these problems a great many historians, probably the vast majority, simply ignored cultural and linguistic theory, dismissing it for what Dror Wahrman once referred to as its "uncompromising constructivism." 15

The interest in agency visible in so many studies of women today has its roots in the "turn" away from this cultural turn and the new emphasis on experience proposed by what Gabrielle Spiegel, among others, has characterized as "practice studies." There have been countless ruminations on "history since the cultural turn" and many excursuses on the theory that helped get us to this place, so here I will use only a few passages from Spiegel's essay to help illuminate the winding path that introduced practice studies and made "agency" so urgent a topic of research for historians, perhaps especially historians of women and gender. ${ }^{16}$ Quoting E. P. Thompson in the Poverty of Theory of 1978 (whose 1968 The Making of the English Working Class mounted the most influential early attack on standard Marxist historiography and opened the way to a rich cultural history of agency), Spiegel observed that practice studies allow us to see that "structure is transformed into process and the subject re-enters history not merely as an expression of larger forces but as a conscious agent who interprets his or her life in terms of cultural norms, tradition, moral and familial values and feelings, and religious beliefs." ${ }^{17}$ In Spiegel's view, if historians follow Thompson's advice and begin with what people actually do, "practice and meaning will be uncoupled from the impersonal workings of discursive regimes and rejoined to the /active/ intentions of human agents imbedded in social worlds." 18 This uncoupling allows, she concludes, "a recuperation of the historical actor as an intentional (if not wholly self-conscious) agent."19 The result is an "emphasis on historically generated and always contingent nature

15 Dror Wahrman, "Change and the Corporeal in Seventeenth and Eighteenth Century Gender History: Or can Cultural History be rigorous?", in Alexandra Shepard and Garthine Walker, eds., Gender and Change:Agency, Chronology and Periodisation (2009):166-191,188.

16 Gabrielle M. Spiegel, ed., Practicing History; New Directions in Historical writing after the Linguistic Turn (Baltimore, Md.: Johns Hopkins University Press, 2005) provides an excellent guide and includes some of the most significant articles published on the issue. Also see, for further discussion, the AHR Forum "Historiographic 'Turns' in Critical Perspective," American Historical Review 117 no. 3 (June, 2012): 698-813.

17 E. P. Thompson, The Poverty of Theory (London: Merlin Press, 1978), 362; in Spiegel, Practicing History, 7 .

18 Spiegel, Practicing History, 3.

19 Spiegel, Practicing History, 4. 
of structures of culture .... that returns us to age-old concerns with processes, agents, change and transformation."20

I want to make a couple of points about this call for practice studies and the agents it calls into being. First, as Spiegel herself points out, this "turn" away from the cultural turn is in some sense a return to the usual work of historians, although in her view (and mine) it does not imply rejection of lessons to be learned from linguistic and cultural theory. Second, it seems that "agency," as understood in this conception of practice studies, can be both conscious and unconscious. Agents can of course understand themselves as strategists, schemers, accommodators, or even resisters but they do not have to be so explicitly intentional. What matters is that they disturb, perhaps even permanently alter, the cultural, social, economic, or political system that constrains them. The question for historians, then, is not just what change they effect or even how they do it. Equally important is the question of how they are enabled or compelled to do so if we accept the central premise of discourse theory that we can operate in society only in terms set by the discursive structures that organize it.

To put this question to rest, we have to find a way around - or through - the paradox Judith Butler named: "the subject who would resist such norms is itself enabled, if not produced, by such norms." ${ }^{21}$ To do so, we have to treat structure and agency as mutually constitutive, not as opposites. It that, as Spiegel put it in her presidential address to the American Historical Association in 2009, historians need to take practice as the "starting point of social analysis, since practice emerges here as the space in which a meaningful interaction between discursive constitution and individual initiative occurs."22 It is those interactions that produce the possibility of agency; they arise from the contradictions inherent in the structures that position people as historical actors. Foucault made precisely this point (although he is sometimes not understood to have done so). Discursive structures are, he insisted, entirely constructed; far from being natural arrangements of meanings, forces, and people into a powerful edifice that combines ideology, law, economy, and social organization, they are cobbled together over time by contests among people for power, stability, and significance. They are necessarily riven by fault lines, some easy to see, others less so. Thus, as Joan Scott recommended in her "Gender as a Useful Category of Historical Analysis" of 1986, "we need to replace the notion that social power

\footnotetext{
20 Spiegel, Practicing History, 25.

21 Judith Butler, Bodies That Matter (New York: Routledge, 1993): 15.

22 Spiegel, "The Task of the Historian," American Historical Review 114 no. 1 (February 2009): 10 .
} 
is unified, coherent, and centralized with something like Foucault's concept of power as dispersed constellations of unequal relationships, discursively constituted in social 'fields of force.' Within these processes and structures, there is room for a concept of human agency as the attempt (at least partially rational) to construct an identity, a life, a set of relationships, a society with certain limits and with language - conceptual language that at once sets boundaries and contains the possibility for negation, resistance, reinterpretation, the play of metaphoric invention and imagination."23

In the particular case of late medieval and early modern Europe, women often found the "room" to which Scott referred as a result of contradictions within specific features of the period's patriarchal discourse. To return to some of the examples mentioned earlier in this essay, a woman in a city like Lyon or Copenhagen might be expected to contribute to the financial support of the household, even to sustain it on her own, and thus had to find ways into the market economy, even if that meant ignoring masculine rights to those places. Similarly, a peasant woman might be positioned as carrier of property from one male line to another, someone with no independent rights to the property, but simultaneously be granted rights before law as the property's possessor. A Protestant daughter could protect, possibly even preach, the faith because Christianity promised women equal access to the divine word even if in that capacity she violated norms about daughterly submission and male leadership of the faith. In each of these cases, it was the women's experience as subjects of a patriarchal regime that, paradoxically, enabled their agency because the patriarchal norm was riven by contradiction. Understood in this way, however, "agency" can seem anything but autonomous; in this conception, "agency" is only action - action born not of individual will but of the experience of living in an inherently unstable patriarchal structure.

We are thus returned to another of Joan Scott's influential articles, "The Evidence of Experience": is there any experience outside the discourse that enables it? ${ }^{24}$ If not, can any individual disrupt the system, i.e., really be an agent of change? My answer to both is "yes," and "yes" to the second because experience sometimes disturbs the discursive structure enough to allow escape from it, whether ideologically or in practice. Women in late medieval and early modern Europe (as elsewhere) experienced such contradictions almost

23 Joan Scott, "Gender as a Useful Category of Historical Analysis," American Historical Review 91 no. 5 (1986): 1053-75,1067; her quote from Foucault is from The History of Sexuality, vol. 1, An Introduction (New York: Vintage, 1980) and Power/Knowledge: Selected Interviews and Other Writings, 1972-77 (New York: Pantheon, 1980).

24 Scott, "The Evidence of Experience," Critical Inquiry 17-4 (Summer 1991): 773-797; reprinted many times, including in Spiegel, Practicing History. 
daily. Scholars could add many examples to those already discussed here. We have long known the story of Margery of Kempe, for example, who insisted on a sexless marriage, thus violating her Christian obligation to pay the conjugal debt even while she simultaneously observed Christian teachings about the sins of the flesh; we have regularly come across proscriptive literature like the Ménagier de Paris, which warned the young wife addressed by the text about the marketplace's threat to female honor even while it carefully instructed her on how to shop; we have many detailed studies that display women who appropriated misogynist narratives defining them as irreducibly "fleshly" to claim spiritual authority. ${ }^{25}$ We also have studies that locate women's agency in larger historical shifts. Some scholars have, for example, argued that in the early modern Netherlands where the market economy was booming single women were able to find paid work outside the family workshop, thus allowing them to make their own marriages - or not to marry at all - giving unexpected (and probably unwelcome) force to the canonical rule that "consent" made marriage. ${ }^{26}$ Other scholars have shown how in the age of the printing press and increased vernacular literacy, women published new kinds of stories about women and men, family, and social order more generally, ones that imagined a different kind of gender binary and different experiences of love. ${ }^{27}$

As we document such varied instances of female agency, however, we also need to be alert to signs that even the most aggressive challenges to patriarchal norms do not necessarily weaken, much less bring an end to, gender hierarchy. As Amy Hollywood noted in a recent article responding to literature on medieval women's ability to redefine spiritual experience by appropriating misogynist narratives about the female body, "medieval women make use of the very gender subordination that constrains them as the condition for and source of agency ... [but this is] an agency ultimately ascribed not to religious women themselves, but to God."28 Making a somewhat similar point, I have elsewhere argued that the expansion of the late medieval market steadily drew women out of subsistence production for the household, making many them

25 Caroline Bynum's Jesus as Mother: Studies of the Spirituality of the High Middle Ages (Berkeley and Los Angeles: University of California Press, 1982) and her Holy Feast Holy Fast (Berkeley and Los Angeles, University of California Press, 1987) examine women's access to spiritual authority.

26 Tine de Moor and Jan Luiten van Zanden, Vrouwen en de geboorte van het kapitalisme in West-Europa (Amsterdam: Boom, 2006); also idem, "Girlpower: the European Marriage Pattern (WMP) and labour markets in the north sea region in the late medieval and early modern period," Economic History Review, 63 no. 1: 1-33.

27 See, for example, Paul Salzman, Early Modern Women's Writing: an Anthology, 1560-1700 (Oxford, U.K.: Oxford U.P, 200o).

28 Amy Hollywood, "Gender, Agency and the Divine in Religious Historiography," The Journal of Religion 84 no. 4 (October, 2004): 514-528, 514. 
active workers in the wage economy, transforming some into independent businesswomen, and in general freeing such women from many of the constraints associated with membership in (and subordination within) a maleheaded household economy. ${ }^{29}$ In origin, however, women's moves into market production were simply in the service of a patriarchal structure that assigned them co-responsibility for household subsistence. As a result of their place in the newly powerful market, however, women entered a public (economic) sphere that was becoming, as Craig Muldrew has pointed out, the site "where social status was communicated." 30 The threat to male privilege was obvious, and subtle backlashes followed. Guilds steadily closed ranks and those that continued to admit women or those that were established to organize female labor during the early modern period were either politically powerless or internally structured to deny women governing authority. In this instance, women's agency was a double-edged sword, both the mark of their presence and influence in an increasingly powerful market economy and the impetus for reforms of the labor market - reforms that confined women workers to undeniably capacious but nevertheless marginalized spaces in the market.

As we look for instances of female agency in late medieval and early modern Europe, we thus need to be attentive to all the complexities that surround this concept. Typically born in the contradictions that are inherent in discursive structures, female agency is more a sign of discursive instability than a signal that the gender system is being fundamentally undermined. Real change, in the sense of a lessening of gender hierarchy, can occur, however, when these disturbances arise from, or even precipitate shifts in, the larger social, political, economic, or cultural order. In such moments, the gender system is necessarily restructured, sometimes in ways that provide women more space and redefine gender codes. Sometimes such shifts even produce ideological upheavals, giving rise to the kind of political self-consciousness that characterizes feminist movements. But such progressive outcomes are not givens. The only certainty is that patriarchy is an unstable construct rooted in the larger social system it both enables and on which it depends. As these structures shift, collide, and morph, agency is produced.

29 Martha Howell, "The Gender of Europe's Commercial Economy, 1200-1700," Gender and History 20 no. 3 (November, 2008): 519-38.

30 Craig Muldrew, The Economy of Obligation: The Culture of Credit and Social Relations in Early Modern England (New York: St. Martin's Press, 1998): 148 and passim. 